Article

\title{
Studies on the Structure, Optical, and Electrical Properties of Doped Manganese (III) Phthalocyanine Chloride Films for Optoelectronic Device Applications
}

\author{
María Elena Sánchez Vergara ${ }^{1, *}$, María José Canseco Juárez ${ }^{1}$, Ricardo Ballinas Indili ${ }^{2}$, Genaro Carmona Reyes ${ }^{2}$, \\ José Ramón Álvarez Bada ${ }^{1}$ and Cecilio Álvarez Toledano ${ }^{2, * \text { (D) }}$ \\ 1 Universidad Anáhuac México, Avenida Universidad Anáhuac 46, Col. Lomas Anáhuac, \\ Huixquilucan 52786, Mexico; maria.cansecoju@anahuac.mx (M.J.C.J.); ramon.alvarez@anahuac.mx (J.R.Á.B.) \\ 2 Instituto de Química, Universidad Nacional Autónoma de México, Circuito Exterior s/n. C.U., \\ Ciudad de México 04510, Mexico; ricardo_snf.49.ers@hotmail.com (R.B.I.); \\ neptuno_genn@hotmail.com (G.C.R.) \\ * Correspondence: elena.sanchez@anahuac.mx (M.E.S.V.); cecilio@unam.mx (C.Á.T.)
}

\section{check for}

updates

Citation: Sánchez Vergara, M.E.; Canseco Juárez, M.J.; Ballinas Indili, R.; Carmona Reyes, G.; Álvarez Bada, J.R.; Toledano, C.Á. Studies on the Structure, Optical, and Electrical Properties of Doped Manganese (III) Phthalocyanine Chloride Films for Optoelectronic Device Applications Coatings 2022, 12, 246. https:// doi.org/10.3390/coatings12020246

Academic Editor: You Seung Rim

Received: 20 January 2022

Accepted: 10 February 2022

Published: 14 February 2022

Publisher's Note: MDPI stays neutral with regard to jurisdictional claims in published maps and institutional affiliations.

Copyright: (C) 2022 by the authors. Licensee MDPI, Basel, Switzerland. This article is an open access article distributed under the terms and conditions of the Creative Commons Attribution (CC BY) license (https:// creativecommons.org/licenses/by/ $4.0 /)$

\begin{abstract}
In the last few years, significant advances have been achieved in the development of organic semiconductors for use in optoelectronic devices. This work reports the doping and deposition of semiconducting organic thin films based on manganese (III) phthalocyanine chloride ( $\mathrm{MnPcCl})$. In order to enhance the semiconducting properties of the $\mathrm{MnPcCl}$ films, different types of pyridinebased chalcones were used as dopants, and their influence on the optical and electric properties of the films was analyzed. The morphology and structure of the films were studied using IR spectroscopy and scanning electron microscopy (SEM). Optical properties of MnPcCl-chalcone films were investigated via UV-Vis spectroscopy, and the absorption spectra showed the $\mathrm{Q}$ band located between 630 and $800 \mathrm{~nm}$, as well as a band related to charge transfer (CT) in the region between 465 and $570 \mathrm{~nm}$ and the B band in the region between 280 and $460 \mathrm{~nm}$. Additionally, the absorption coefficient measurements indicated that the films had an indirect transition with two energy gaps: the optical bandgap of around $1.40 \mathrm{eV}$ and the fundamental gap of around $2.35 \mathrm{eV}$. The electrical behavior is strongly affected by the type of chalcone employed; for this reason, electrical conductivity at room temperature may vary from $1.55 \times 10^{-5}$ to $3.02 \times 10^{1} \mathrm{~S} \cdot \mathrm{cm}^{-1}$ at different voltages $(0.1,0.5$, and $1.0 \mathrm{~V})$. Additionally, the effect of temperature on conductivity was also measured; electrical conductivity increases by two orders of magnitude with increasing temperature from 25 to $100{ }^{\circ} \mathrm{C}$. The doping effect of chalcone favors electronic transport, most likely due to its substituents and structure with delocalized $\pi$-electrons, the formation of conduction channels caused by anisotropy, and the bulk heterojunction induced by the dopant. In terms of optical and electrical properties, the results suggest that the best properties are obtained with chalcones that have the methoxy group as a substituent. However, all $\mathrm{MnPcCl}$-chalcone films are candidates for use in optoelectronic devices.
\end{abstract}

Keywords: organic semiconductor film; chalcones; optical properties; flexible device; electrical properties

\section{Introduction}

Organic photovoltaics is a field of research that has been growing steadily in the last decade, leading to values of power conversion efficiency currently surpassing $10 \%$ [1-5]. The first organic photovoltaic cells, or organic solar cells, were manufactured more than 20 years ago and had an efficiency of around $1.7 \%$. Nowadays, there are organic solar cells with an efficiency of about 18\% [4-6]. This type of cell is made from organic semiconductors (OS) with a delocalized $\pi$-electron system. OS can absorb sunlight to create photo-generated charge carriers and transport these charge carriers $[7,8]$. The use of OS has many advantages, such as (i) low-cost synthesis, (ii) capability for optoelectronic-property modulation of some materials, given the versatility of their synthetic methodologies, (iii) high molar 
extinction coefficients, which permits working with very thin films of these semiconductors and reducing the amount of material used, and (iv) easy manufacture of thin-film devices by vacuum evaporation/sublimation, solution cast, or printing technologies [8]. However, the use of these types of materials also has some disadvantages. For instance, OS can be regarded as "intrinsic wide bandgap semiconductors", with a low intrinsic charge carrier density at room temperature in the dark [8], which leads to low current densities. Nevertheless, chemical or molecular doping, which consists of mixing the OS with another molecule with a strong electron-donor or electron-acceptor character, can increase the number of charge carriers, which eases electronic transfer between both species when they are at a very short distance. In p-type doping, the semiconductor is intentionally "contaminated" with strongly oxidizing molecules, while, in n-type doping, strongly reducing molecules are added. Among the molecules widely used as OS, one may consider phthalocyanines (Pcs) and particularly metallophthalocyanines (MPcs), with metallic ions in their cores. MPcs are macrocycles made up of $18 \pi$-electrons with exceptional properties due to delocalization, such as high chemical, thermal, and photochemical stabilities and appropriate redox properties. They also have a wide absorption region in their infrared/near-infrared spectra, as well as optical nonlinearity related to their wide range of semiconducting properties [9-13]. Thanks to these remarkable electronic and optical properties, MPc thin films represent an area of outstanding research for organic electronic devices [13-15]. For example, in recent years, MPcs have been implemented in perovskite solar cells as hole transport materials (HTMs), scoring in some cases efficiencies above 20\% [12,16-18]. MPcs are also attractive building blocks in molecular donor-acceptor $(\mathrm{D}-\mathrm{A})$ systems because of their ability to efficiently absorb light in the visible region, as well as their capability to perform as electron donors (D) upon photoexcitation in various D-A systems [19-23].

With these issues in mind, there is a natural interest in researching potential synergies arising from the interaction between MPc cores and other stable organic materials, such as chalcones, which are molecules of easy synthesis and low cost. In this work, we report the doping and characterization of thin films of manganese (III) base phthalocyanine chloride (Figure 1). These films were used to manufacture optoelectronic devices whose properties were then evaluated, considering the structural features of each chalcone used as dopant (see Figure 1). The justification for this work considers several issues. (i) This study proposes the use in optoelectronics devices of Pcs containing a center of Mn with electronic structure $3 \mathrm{~d}^{5}$, with the intention that the Mn-3d orbitals may approach the Fermi level [24,25]. (ii) Phthalocyanines with manganese chloride are relevant in this regard because this type of Pcs exhibits distinctive optical properties [26-28] and photoelectric behavior worthy of attention [29,30]. (iii) Most of the research about Pcs applied in molecular electronics is related to MPcs of divalent metals, such as $\mathrm{ZnPc}, \mathrm{CuPc}$, and $\mathrm{MgPc}[1,9,19-23,31]$ or $\mathrm{MPcCl}$ compounds, as $\mathrm{AlPcCl}[26,32-34]$ and $\mathrm{GaPcCl}[27,28,32,35]$, while there are comparatively few studies of the optical and electrical properties of $\mathrm{MnPcCl}$ films $[24,25,36]$. (iv) Finally, one contribution of this work lies in reporting and investigating the doping of $\mathrm{MnPcCl}$ with chalcones as a way to enhance its properties and optoelectronic applications.

The chalcones are a class of compounds that contain different types of substituents in their structure, connected through a three-carbon bridge with a keto carbonyl group and an $\alpha, \beta$-unsaturation $[37,38]$. When chalcone contains aromatic rings in its structure, the $\alpha$, $\beta$-unsaturation carbonyl system may exhibit increased electron delocalization [37]. Some chalcones have shown nonlinear optical properties contributing to material developments associated mainly with electronic applications [37-42], for example, in fields such as electrochemical sensing [43], optical limiting materials [44], and Langmuir films [45]. Moreover, chalcone derivatives are thermally stable up to their melting point, which makes them suitable candidates for doping stable host material in order to improve its photophysical properties [46,47]. In addition, it has been reported that the introduction of heterocyclic rings into the chalcone moiety increases the stability of chalcones in comparison with the parent trans-chalcone, with the disadvantage that heterocyclic chalcones are commonly less soluble [48]. Heterocyclic chalcones are soluble in nonprotic organic solvents, such as 
dichloromethane, chloroform, and ethyl acetate. As the polarity of the solvents increases, they become less soluble, mainly in polar protic solvents, such as methanol and ethanol, where their solubility is moderate, probably due to their stronger intermolecular interactions arising from the functionalized rings [48]. Specifically, the pyridylchalcones used in this work (Figure 1) are quite stable at ambient conditions and do not undergo any type of change in their physical and chemical properties when stored for long periods of time. Due to this background and based on the number of chalcone derivatives that have been used in the manufacture of optoelectronic devices, we decided to study the role of pyridylchalcones in the manufacture of doped films for optoelectronic device applications.

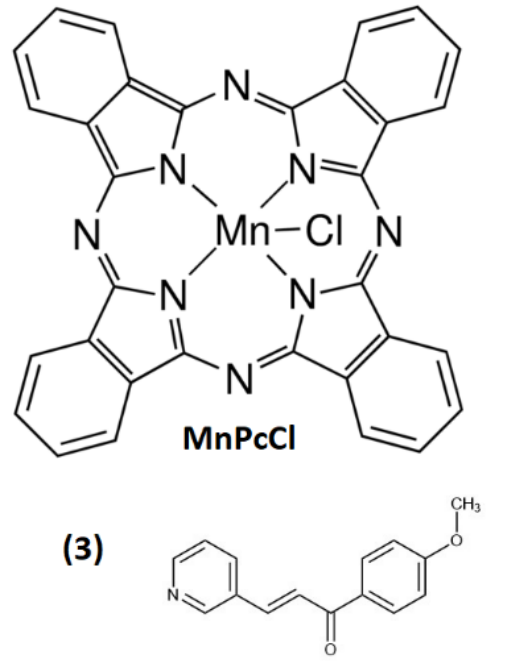

(E)-1-(4-methoxyphenyl)-3-(pyridin-3-yl)prop-2-en-1-one
(1)<smiles>COc1ccccc1C(=O)/C=C/c1cccnc1</smiles>

(E)-1-(2-methoxyphenyl)-3-(pyridin-3-yl)prop-2-en-1-one

(2)<smiles>COc1ccc(C(=O)/C=C/c2ccccn2)cc1</smiles>

(E)-1-(4-methoxyphenyl)-3-(pyridin-2-yl)prop-2-en-1-one

(4)<smiles>O=C(/C=C/c1ccccn1)c1cccc(C(F)(F)F)c1</smiles>

(5)<smiles>O=C(/C=C/c1cccnc1)c1ccccc1Br</smiles>

(E)-3-(pyridin-2-yl)-1-(3-(trifluoromethyl)phenyl)prop-2-en-1-one

(E)-1-(2-bromophenyl)-3-(pyridin-3-yl)prop-2-en-1-one

Figure 1. Structure of $\mathrm{MnPcCl}$ and chalcones.

Although numerous studies have been conducted on chalcone derivatives, studies of chalcone thin films are lacking [38,49-51]. Hence, in this work, we investigated the structural, morphological, optical, and electrical properties of $\mathrm{MnPcCl}-$ chalcone thin films. Different chalcones were used as dopants (Figure 1), and the doped films were deposited using vacuum evaporation technology. The use of chalcones to enhance the properties of the manufactured doped films was devised due to the facility to produce compounds with increased electron delocalization. Since these features can be easily covered with simple chalcones, we decided to use easily accessible pyridilchalcones. UV-visible studies with chalcones containing pyridine moieties reveal that the material has sufficient transmission in the entire visible region and a wide optical band gap of $3.35 \mathrm{eV}$. These studies indicate that the chalcone films can be promising candidates for optoelectronic applications and in other photonic devices due to their large optical band gap and good thermal stability [52]. The structure and morphology of films were studied by infrared (IR) spectroscopy and scanning electron microscopy (SEM). Subsequently, the dopant effect on the optical parameters and energy gap of the thin films was examined by UV-vis spectroscopy. Finally, flexible devices were produced with each of the chalcone-doped films, and their electrical behavior was later characterized. 


\section{Materials and Methods}

\subsection{Doping of Organic Semiconductors (OSC)}

All reagents and solvents were obtained from commercial sources and used without further purification (Sigma-Aldrich, Saint Louis, MO, USA). Chalcones were used in this study as organic dopants (see Figure 1), and their synthesis was carried out according to the procedure reported previously by some of the authors of this work [53]. Subsequently, manganese (III) phthalocyanine chloride, $\mathrm{MnPcCl}\left(\mathrm{C}_{32} \mathrm{H}_{16} \mathrm{ClMnN}_{8}\right)$ was chemically doped with chalcones by a simple reaction in absolute methanol in a conventionally heated Monowave 50 reactor with a pressure sensor (Anton Paar México, S.A. de C.V. Hidalgo, México). Afterward, $181 \mathrm{mg}(0.3 \mathrm{mmol})$ of $\mathrm{MnPcCl}$ were added to $47.8 \mathrm{mg}(0.2 \mathrm{mmol})$ of chalcone No. 1 (OS1), or $47.8 \mathrm{mg}(0.2 \mathrm{mmol})$ of chalcone No. 2 (OS2), or $47.8 \mathrm{mg}(0.2 \mathrm{mmol})$ of chalcone No. 3 (OS3), or $55.4 \mathrm{mg}(0.2 \mathrm{mmol})$ of chalcone No. 4 (OS4), or $57.6 \mathrm{mg}$ $(0.2 \mathrm{mmol})$ of chalcone No. 5 (OS5), respectively and then dissolved in $6 \mathrm{~mL}$ of absolute methanol. The reactor was operated with a borosilicate glass vial and manually closed by a cover with an integrated pressure ( $0-20$ bar) and temperature sensor. Every compound remained on reflux for $40 \mathrm{~min}$ using a 2-step method: ramp to temp for $10 \mathrm{~min}$ at $140{ }^{\circ} \mathrm{C}$ and hold time for $30 \mathrm{~min}$ at $140{ }^{\circ} \mathrm{C}$, with a stirrer speed of $600 \mathrm{rpm}$ and a cooling temperature of $30{ }^{\circ} \mathrm{C}$. The doped semiconductors were then filtered, purified, and dried in a vacuum. These doped semiconductors are insoluble in organic solvents, such as ethanol, acetone, isopropanol, and methanol. In order to verify the purity of the doped semiconductors, thin plate chromatography was applied to all of them. Finally, to verify the main functional groups of the organic semiconductors, IR-spectroscopy analysis was performed on a Nicolet iS5-FT spectrometer (Thermo Fisher Scientific Inc., Waltham, MA, USA), using KBr pellets on a wavelength range of 4000 to $500 \mathrm{~cm}^{-1}$.

\subsection{Thin Film Deposition and Characterization}

Organic semiconductors OS1, OS2, OS3, OS4, and OS5 were subsequently deposited using the high-vacuum sublimation technique. The substrates were made from polyethylene terephthalate film, ITO coated (PET-ITO) monocrystalline n-type and p-type silicon wafers, and Corning glass. Except for the substrate PET-ITO, all other substrates were previously submitted to a sonication cleaning process with different solvents and were dried under a vacuum. The organic semiconductors were deposited by sublimation on a vacuum chamber (Intercovamex, S.A. de C.V., Cuernavaca, Morelos, Mexico). The vacuum was accomplished through two pumps: a mechanical pump that generated an initial pressure of $10^{-3}$ Torr and a turbo-molecular pump that generated the final deposition pressure of $10^{-6}$ Torr. The deposition process involved evaporation equipment with molybdenum and tantalum boats. During the deposition processes, the film thickness was evaluated with a high-resolution thickness monitor and a SISMONI-1C-3mHz quartz sensor (Intercovamex, S.A. de C.V., Cuernavaca, Morelos, Mexico). A further IR analysis was carried out in the film deposited on the n-type silicon wafers with a Nicolet iS5-FT (Thermo Fisher Scientific Inc., Waltham, MA, USA). A ZEISS EVO LS 10 scanning electron microscope (Zeiss International Inc., Göttingen, Germany) was used to analyze the thin films supported by the glass substrate. The films on glass substrates were also used to determine the optical absorption of the materials with a Unicam spectrophotometer, model UV300 (Thermo Fisher Scientific Inc., Waltham, MA, USA), in the wavelength range of 200-1100 nm. In order to estimate the charge-carrying properties of the doped semiconductors, a flexible device was manufactured. The doped semiconductor BHJ film was placed between the ITO (anode) and the conductive carbon paint (cathode). The thickness and area of the $\mathrm{MnPcCl}-$ chalcone $\mathrm{BHJ}$ were $76 \mathrm{~nm}$ and $4.61 \mathrm{~cm}^{2}$, respectively. Electric measurements were performed with a programmable voltage source, namely the Keithley 4200-SCS-PK1 autoranging pico-ammeter (Tektronix Inc., Beaverton, OR, USA). The evaluation of the electrical behavior of the devices was performed with the voltage source and a sensing station with a lighting- and temperature-controller circuit from Next Robotix (Comercializadora KMox, S.A. de C.V., Mexico City, Mexico). 


\section{Results and Discussion}

\subsection{Doping, Deposition, and Characterization of the Semiconductor Films}

The doping of $\mathrm{MnPcCl}$ with chalcone molecules was carried out as described in the experimental section. The IR spectra shown in Figure 2a were performed to verify the presence of the main functional groups in the doped $\mathrm{MnPcCl}$-chalcone (OS1, OS2, OS3, OS4, and OS5) in $\mathrm{KBr}$ and, based on these results, determine the viability of depositing the thin films by means of the vacuum evaporation technique. Vacuum evaporation is a clean technique for thin film deposition, as a vacuum is applied to reduce contaminants such as oxygen and water and, on the other hand, to dope and create interpenetrating donor-acceptor networks [8]. However, the thermal gradients generated during the deposition can chemically break down the semiconductor molecules; hence, the importance of IR spectroscopy. The signals corresponding to both $\mathrm{MnPcCl}$ and chalcone in $\mathrm{KBr}$ pellets can be identified in Figure 2a. Regarding $\mathrm{MnPcCl}$ in the spectrum, the band responsible for the pyrrole in-plane stretch vibration in the phthalocyanine ring is observed around $1333 \mathrm{~cm}^{-1}$, and the bands located around 1166, 1119, and $753 \mathrm{~cm}^{-1}$ result from the interaction between carbon and hydrogen atoms $[31,37,54]$. The $\alpha$-form in $\mathrm{MnPcCl}$ can be characterized by a band around $727 \mathrm{~cm}^{-1}$, while the $\beta$-form can be characterized by a band around $782 \mathrm{~cm}^{-1}[37,55]$. The difference between the crystalline structures is the angle formed between the symmetry axis and the stacking direction (see Figure $2 b$ ). The $\alpha$-form has an angle $\theta=26.5^{\circ}$ with this axis, while the $\beta$-form has an angle $\theta=45.8^{\circ}[37,55]$. According to the IR spectra, $\mathrm{MnPcCl}$ in the doped materials has both crystalline forms. As for the chalcones used as dopants, the IR spectrum of Figure 2a shows the band corresponding to carbonyl at around $1669 \mathrm{~cm}^{-1}$; it is also possible to observe the signal corresponding to the double $\mathrm{C}=\mathrm{C}$ bonds in the neighborhood of $1610 \mathrm{~cm}^{-1}$. After vacuum evaporation, IR spectroscopy was performed again, now on the $\mathrm{MnPcCl}$-chalcone films deposited on n-type silicon. The results are shown in Table 1, in which the vibrational modes of the films are also compared with those obtained for these materials in $\mathrm{KBr}$ pellets. Both vibrational modes are similar, with a small difference due to film stress attributed to the deposition process. From the above, it is concluded that the $\mathrm{MnPcCl}-$ chalcone doped semiconductors did not suffer any degradation during the formation of the thin films.

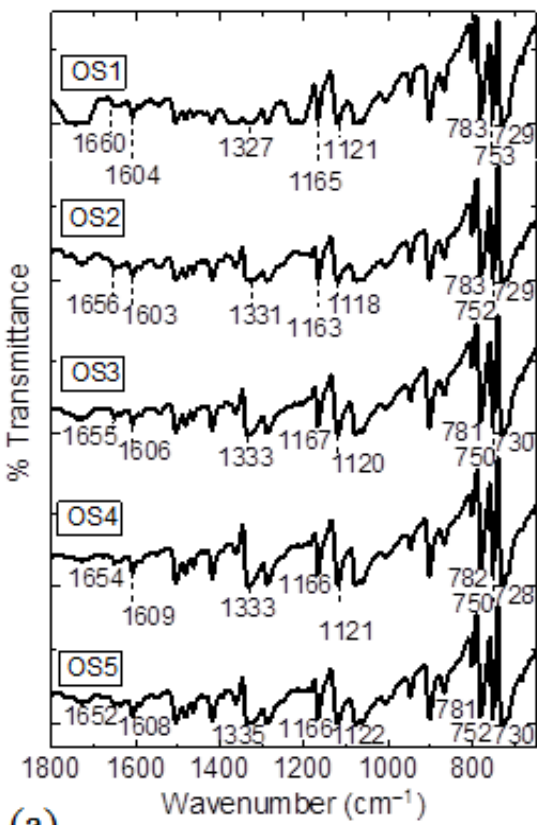

(a)

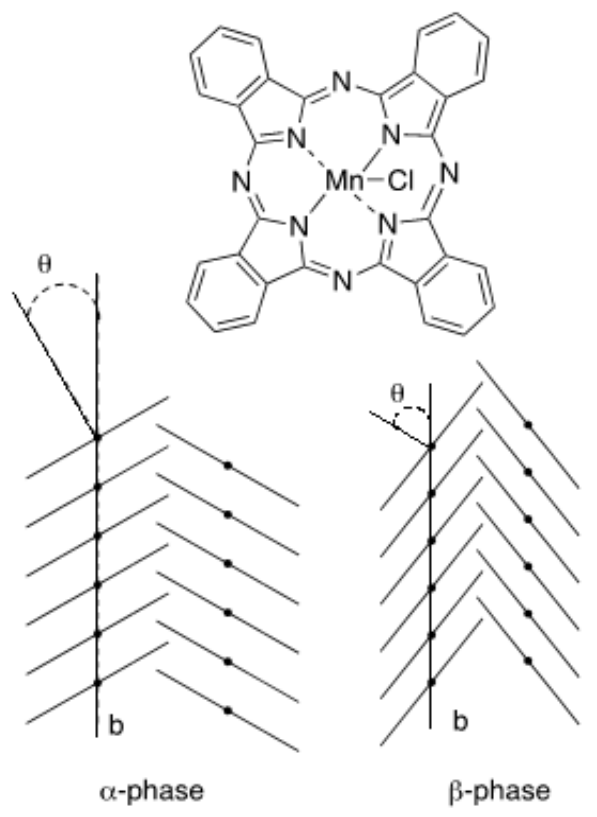

(b)

Figure 2. (a) IR spectra of doped semiconductors in KBr pellets. (b) Structure of $\alpha$ and $\beta$-form for $\mathrm{MnPcCl}$. 
Table 1. Band positions and assignments of $\mathrm{MnPcCl}-$ chalcone semiconductors in $\mathrm{KBr}$ pellets (powder) and films.

\begin{tabular}{|c|c|c|c|c|c|c|c|c|c|c|}
\hline Assignment & $\begin{array}{l}\text { Powder } \\
\left(\mathrm{cm}^{-1}\right)\end{array}$ & $\underset{\left(\mathrm{cm}^{-1}\right)}{\text { Film }}$ & $\begin{array}{l}\text { Powder } \\
\left(\mathrm{cm}^{-1}\right)\end{array}$ & $\begin{array}{l}\text { Film } \\
\left(\mathrm{cm}^{-1}\right)\end{array}$ & $\begin{array}{l}\text { Powder } \\
\left(\mathrm{cm}^{-1}\right)\end{array}$ & $\underset{\left(\mathrm{cm}^{-1}\right)}{\text { Film }}$ & $\begin{array}{l}\text { Powder } \\
\left(\mathrm{cm}^{-1}\right)\end{array}$ & $\begin{array}{l}\text { Film } \\
\left(\mathrm{cm}^{-1}\right)\end{array}$ & $\begin{array}{l}\text { Powder } \\
\left(\mathrm{cm}^{-1}\right)\end{array}$ & $\underset{\left(\mathrm{cm}^{-1}\right)}{\text { Film }}$ \\
\hline Sample & OS1 & OS1 & OS2 & OS2 & OS3 & OS3 & OS4 & OS4 & OS5 & OS5 \\
\hline $\begin{array}{l}\text { In-plane pyrrole } \\
\text { stretching }\end{array}$ & 1327 & 1335 & 1335 & 1333 & 1332 & 1332 & 1334 & 1331 & 1332 & 1333 \\
\hline $\mathrm{C}-\mathrm{H}$ bending & $\begin{array}{l}1164 \\
1119\end{array}$ & $\begin{array}{l}1161 \\
1119\end{array}$ & $\begin{array}{l}1167 \\
1119\end{array}$ & $\begin{array}{l}1167 \\
1121\end{array}$ & $\begin{array}{l}1167 \\
1119\end{array}$ & $\begin{array}{l}1165 \\
1121\end{array}$ & $\begin{array}{l}1166 \\
1120\end{array}$ & $\begin{array}{l}1165 \\
1119\end{array}$ & $\begin{array}{l}1166, \\
1119\end{array}$ & $\begin{array}{l}1167 \\
1119\end{array}$ \\
\hline $\begin{array}{l}\text { In-plane C-H } \\
\text { deformation }\end{array}$ & 753 & 752 & 753 & 752 & 753 & 754 & 753 & 754 & 752 & 754 \\
\hline$\alpha$-form in $\mathrm{MnPc}$ & 729 & 726 & 724 & 726 & 729 & 727 & 729 & 726 & 727 & 724 \\
\hline$\beta$-form in $\mathrm{MnPc}$ & 783 & 782 & 782 & 779 & 782 & 780 & 782 & 778 & 782 & 778 \\
\hline $\begin{array}{l}\mathrm{C}=\mathrm{O} \text { stretching } \\
\text { bands of carbonyl }\end{array}$ & 1660 & 1662 & 1656 & 1665 & 1656 & 1662 & 1652 & 1668 & 1652 & 1667 \\
\hline $\begin{array}{c}\mathrm{C}=\mathrm{C} \text { bending of } \\
\text { chalcone }\end{array}$ & 1607 & 1604 & 1609 & 1609 & 1607 & 1608 & 1607 & 1607 & 1607 & 1603 \\
\hline
\end{tabular}

The morphology of the films was studied at different magnifications through SEM; Figure 3 shows the microphotographs at $250 \times$ (Figure 3a) and 1250× (Figure 3b). The study at high magnifications was carried out with the purpose of looking for micrometric-sized imperfections in the films, which can affect charge transport and, in general, electrical behavior. The study at low magnifications, in addition to looking for imperfections in the films, helped to analyze their morphology on a larger surface. With both magnifications, practically the same morphologies are observed. The difference in the chalcone used as dopant apparently does not influence the quality of the deposit. Regardless of the dopant used, a homogeneous morphology formed by fine grains and a free surface without holes are observed. There seems to be only one phase, which is an indication of an adequately dispersed heterojunction in each of the films. At 250×, the particles that are observed on the surface of films OS2 and OS3 are a product of the deposition process and can be removed mechanically with the help of nitrogen flow. From the results obtained, one may observe that the quality of the films mainly depends on the operating parameters during their manufacture, which was similar for all the deposits. Vacuum evaporation is a technique that allows the formation of homogeneous $\mathrm{MnPcCl}$-dopant films; this uniformity enhances their optical and electric properties.

\subsection{Optical Behavior Evaluation}

The absorption of light by organic semiconductors gives an insight into their electronic transfer characteristics. For this reason, UV-vis spectroscopy was carried out in the precursors in solid-state form and in the $\mathrm{MnPcCl}$-chalcone films deposited on Corning glass. According to the literature, the spectrum of the chalcones in Figure 4a shows the absorption peaks in the region between 290 and $397 \mathrm{~nm}$ [56,57]. Figure 4b shows the UV-vis spectra for the $\mathrm{MnPcCl}$-chalcones films, which were strongly influenced by the presence of $\mathrm{MnPcCl}$. Phthalocyanines are compounds with high optical stability that absorb radiation corresponding to the visible portion of the electromagnetic spectrum. The UV-vis spectrum of the $\mathrm{MnPcCl}$ in Figure 4a presents three absorption bands in the visible region: the $\mathrm{Q}$ band, a band related to charge transfer (CT), and the $\mathrm{B}$ band $[13,36,58,59]$. The $\mathrm{Q}$ band is associated with $\pi-\pi^{*}$ transitions from the Highest Occupied Molecular Orbital (HOMO) to the Lowest Unoccupied Molecular Orbital (LUMO) between orbitals of symmetry $a_{u}$ and $b_{g}$, respectively. According to the spectra shown in Figure $4 \mathrm{~b}$ for the $\mathrm{MnPcCl}-\mathrm{chalcone}$ films, this band is located between $630-800 \mathrm{~nm}$ and is responsible for the blue-green coloration of these materials. It is important to consider that the interval between 630 and $800 \mathrm{~nm}$ is 
characterized by a high absorption; the edge of photoabsorption corresponds mainly to the visible range of the spectrum, which is a relevant feature for photovoltaic systems [36]. On the other hand, the CT band is located between 465 and $570 \mathrm{~nm}$ and is associated with unsaturated manganese ions. Finally, the B band at region $280-460 \mathrm{~nm}$ is due to more energetic electronic transitions, related to $\pi-\pi^{*}$ transitions from occupied orbitals of symmetry $b_{u}$ and $a_{u}$ at lower energies than the LUMO. It is important to consider that this band is also influenced by the chalcone used as a dopant $[46,56,60]$. The spectrum has maximum absorption in the region $360-390 \mathrm{~nm}$, which corresponds to the $\pi \rightarrow \pi^{*}$ transition for the chalcones $[46,56,60]$. Figure $4 \mathrm{c}$ shows the transmittance for the $\mathrm{MnPcCl}-$ chalcone films over Corning glass; the spectra show a peak at $470 \mathrm{~nm}$, reaching a transmittance of $27 \%$ [36]. Two more peaks have been identified at 570 and around $925 \mathrm{~nm}$ for $\mathrm{MnPcCl}-\mathrm{chalcone}$ films, suggesting potential applications for these films in photovoltaics, photodiodes, and photo sensors [36,61]. Finally, in the spectra of Figure 4, changes in film absorbance and transmittance can be observed. The structure of the chalcone acting as a dopant seems to cause these modifications. For example, the highest overall absorption and lowest transmission have corresponded to semiconductor film OS1, while the lowest absorption and highest transmission were observed in film OS3. It is interesting to notice that chalcones one and three have a similar structure (see Figure 1), as both have a pyridine in position three and are only distinguished by a position change of the methoxy group $\left(-\mathrm{OCH}_{3}\right)$ in the aromatic ring. It seems that the position change of the $-\mathrm{OCH}_{3}$ group (from para- to ortho-) modifies the optical behavior, given that electronic delocalization in chalcone is affected by the presence of the carbonyl group as well as by the position of the $-\mathrm{OCH}_{3}$ group, which in the ortho- pattern may be interacting with the carbonyl by a hydrogen bond through the vinyl hydrogen $\alpha$.

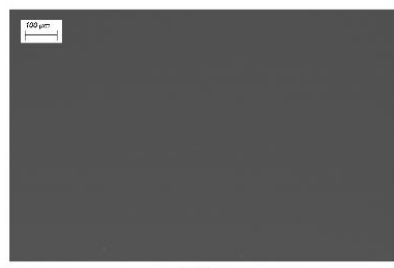

OS1

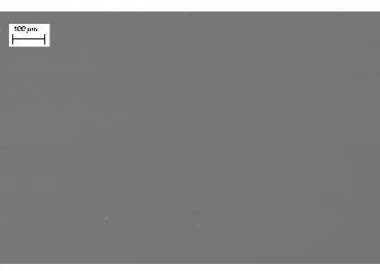

OS4

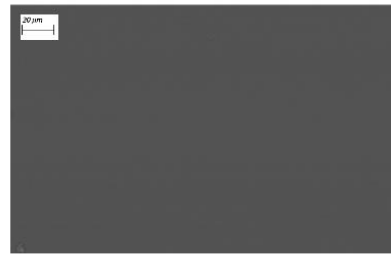

os1

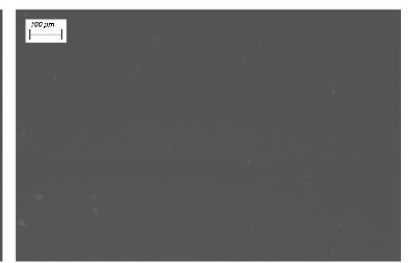

OS2

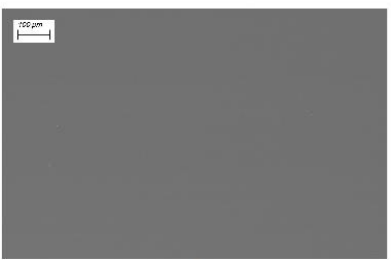

OS5

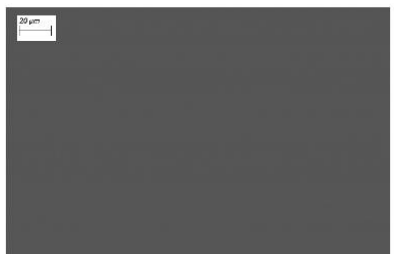

OS2

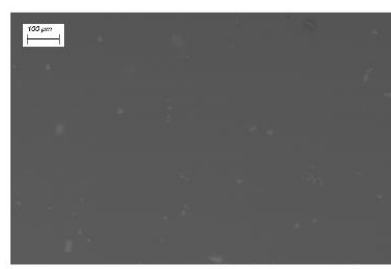

os3

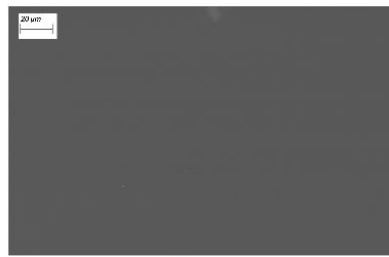

os3

(b)
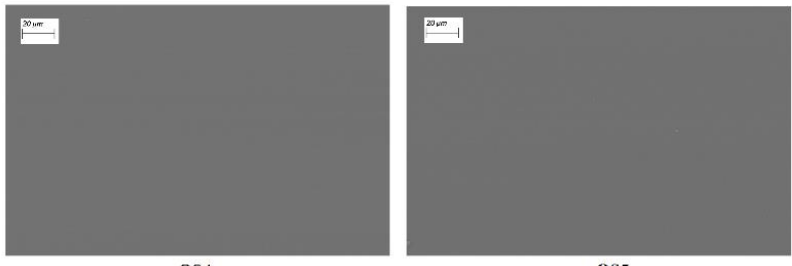

OS5

Figure 3. SEM micrographs of $\mathrm{MnPcCl}-$ chalcone films at (a) $250 \times$ and (b) $1250 \times$. 
(a)

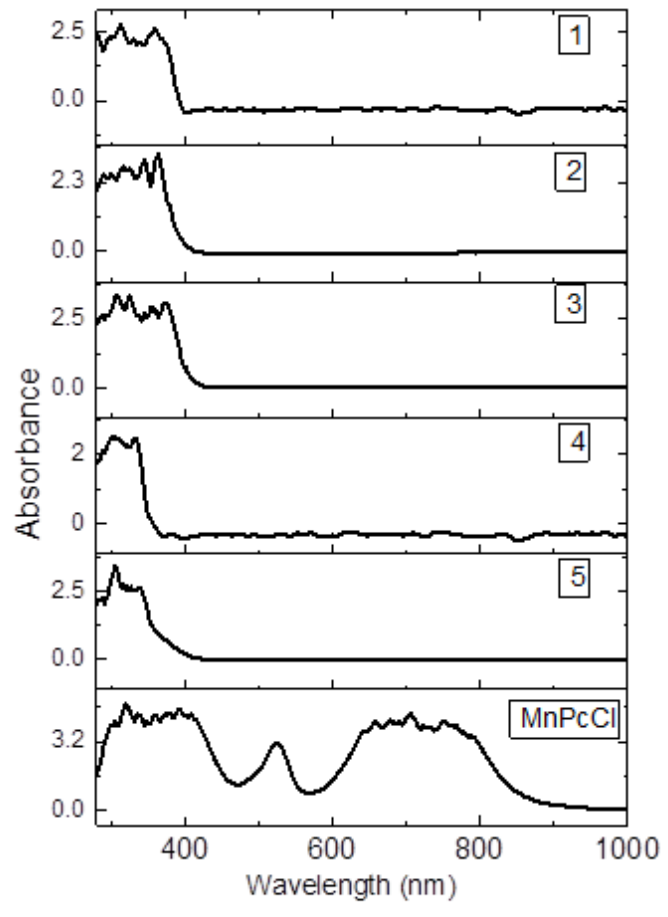

(b)

(c)
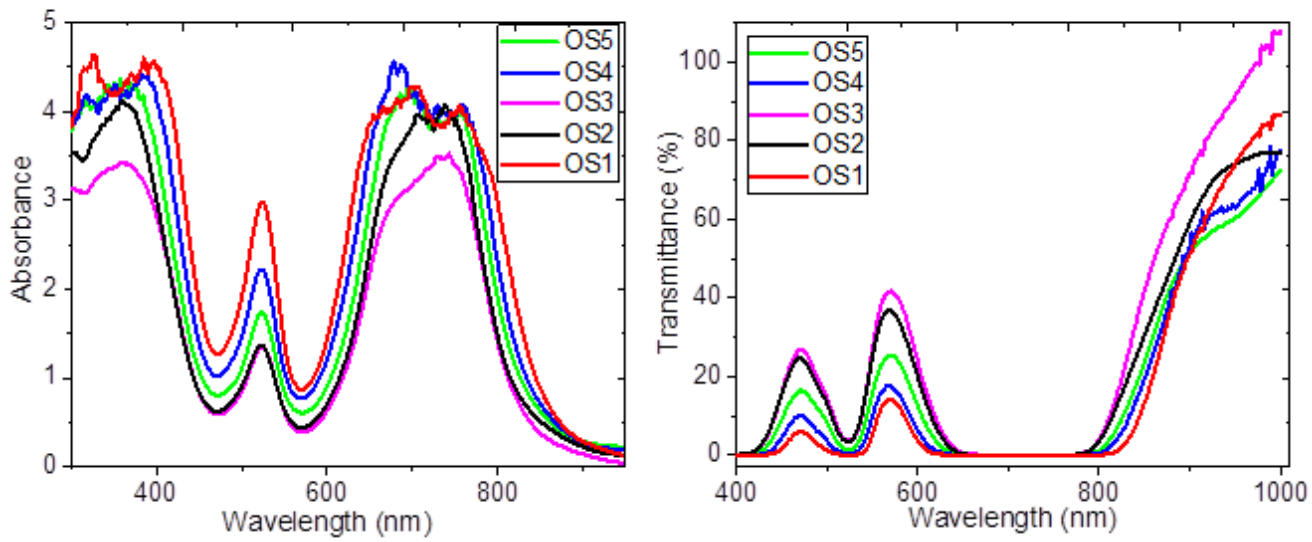

Figure 4. (a) Absorbance of $\mathrm{MnPcCl}$ and chalcones 1-5. (b) Absorbance and (c) transmittance optical spectra of $\mathrm{MnPcCl}-$ chalcone films.

The absorption coefficients, $\alpha$, for $\mathrm{MnPcCl}-$ chalcone films, as functions of wavelength, are shown in Figure 5a. In order to calculate $\alpha$, the following expression is used:

$$
\alpha=\ln (T / d)
$$

where $d$ is the thickness of the films and $T$ is their transmittance. It can be observed that $\alpha$ values are in the range of $10^{5}-10^{7} \mathrm{~cm}^{-1}$ and are superior to those reported for pristine $\mathrm{MnPcCl}$ [27], as well as for other MPcs [26,62]. In this case, the value of $\alpha$ changes drastically, depending on the type of chalcone used as a dopant. Chalcones have remarkable linear and nonlinear optical properties [37-43] and, according to the results obtained by Maidur et al. $[46,56]$, the presence of chalcones increases film absorption. On the other hand, most electronic transitions in organic semiconductors occur between the HOMO and the LUMO, with the bandgap representing the region between them. If $\alpha \geq 10^{-4} \mathrm{~cm}^{-1}$, there is a general expression that relates $\alpha$ to the energy bandgap [63]. The energy dependence of $\alpha$ is given by Tauc's relationship [36,62-65]:

$$
(\alpha \mathrm{h} v)=A\left(\mathrm{~h} v-\mathrm{E}_{\mathrm{g}}\right)^{\mathrm{r}}
$$



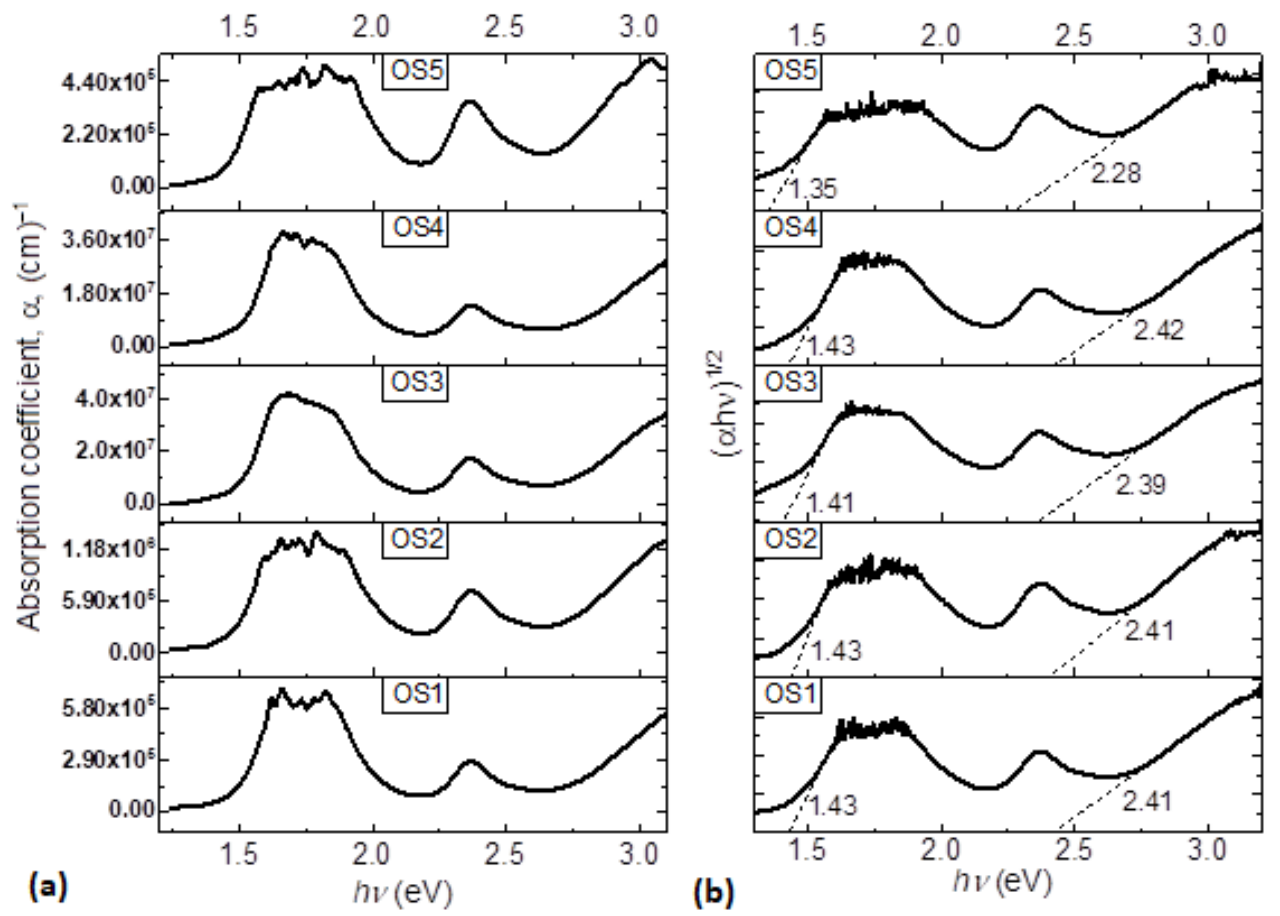

Figure 5. (a) Absorption coefficients, $\alpha$, and (b) plots of $(\alpha \mathrm{h} v)^{1 / 2}$ versus photon energy (hv) of the $\mathrm{MnPcCl}$-chalcone films.

Parameter $A$ depends on the transition probability, $\mathrm{E}_{\mathrm{g}}$ is the energy band gap, $\mathrm{h} v$ is the photon energy, and $\mathrm{r}$ is a number that characterizes the transition process and takes the value $r=2$ for indirect transitions in amorphous films [66,67]. Figure 5b shows Tauc's plots of the films, from which the $\mathrm{E}_{\mathrm{g}}$ values could be calculated by extrapolating a tangent line to the hv axis. According to Figure 5b, the band gap values change slightly as a result of modifications in the chalcone structure. Figure $5 b$ shows two energy band gaps: the optical band gap ( $\left.\mathrm{E}_{\mathrm{g}}{ }^{\mathrm{opt}}\right)$ at low hv and the fundamental gap $\left(\mathrm{E}_{\mathrm{g}}\right)$ at high $\mathrm{hv}$ [36]. The $\mathrm{E}_{\mathrm{g}}{ }^{\text {opt }}$ value corresponds to transitions from the HOMO to the LUMO level, and the $E_{g}$ value results from transitions corresponding to the $3 \mathrm{~d} \rightarrow \pi^{*}$ orbit energy bands $[36,68]$. $\mathrm{E}_{\mathrm{g}}{ }^{\mathrm{opt}}$ values for the films were found between 1.35 and $1.43 \mathrm{eV}$, while the $\mathrm{E}_{\mathrm{g}}$ values were located between 2.28 and $2.42 \mathrm{eV}$. The values of $\mathrm{E}_{\mathrm{g}}{ }^{\mathrm{opt}}$ and $\mathrm{E}_{\mathrm{g}}$ are within the range of band gaps reported in the literature and are also obtained by Tauc's method for films based on $\mathrm{MnPcCl}[24,36,69]$. It is important to mention as well that, in all cases, the band gap is also within the range accepted for organic semiconductors (whose limit is $3 \mathrm{eV}$ ). The low $\mathrm{E}_{\mathrm{g}}{ }^{\mathrm{opt}}$ values obtained in this work suggest that films with $\mathrm{MnPcCl}$-chalcone may be good candidates for use in optoelectronic devices, as $\mathrm{E}_{\mathrm{g}}{ }^{\mathrm{opt}}$ defines the nature of the electroluminescent signal in light-emitting diodes and light absorption efficiency in solar cells. To provide further evidence in this regard, an evaluation of the electric behavior is relevant at this point.

\subsection{Manufacture of the Devices and Electrical Characterization}

Flexible devices were manufactured in order to evaluate the electric behavior of the $\mathrm{MnPcCl}-$ chalcone films. A schematic diagram of the devices is shown in Figure 6. The active layer was constituted by $\mathrm{MnPcCl}-$ chalcone; thus, at any point within the film, there is a donor-acceptor mixture. The bulk heterojunction $(\mathrm{BHJ})$ is intended to increase the interface area between the two species while reducing the distance between them, which promotes the excitonic dissociation processes and reduces the recombination processes $[24,70,71]$. The transparent substrate used in the manufacture of the device is made of PET, the anode is made of a transparent ITO conductor, and the cathode is made of graphite, also a conductor. The performance of the device is best illustrated by its current-voltage $(I-V)$ characteristics. The forward- and reverse-bias $I-V$ characteristics of the $\mathrm{MnPcCl}$-chalcone $\mathrm{BHJ}$ films at room 
temperature are shown in Figure 7a-e. The highest current value was recorded in the device with the OS3 film, followed by OS1, OS2, OS4, and OS5. Such a result might be indicative of a more efficient charge injection from film OS3. This fact could be due to a lower injection barrier between such film and the electrode leading to efficient charge transport between $\mathrm{MnPcCl}$ and the chalcone three. Chalcones with a methoxy group donate electron density through the aromatic ring, so they may be considered partial electron donors. The presence of the methoxy group in OS1, OS2, and OS3 (see Figure 1), conversely, promotes a partial electron acceptor behavior in $\mathrm{MnPcCl}$, facilitating charge transport in the $\mathrm{BHJ}$ film.

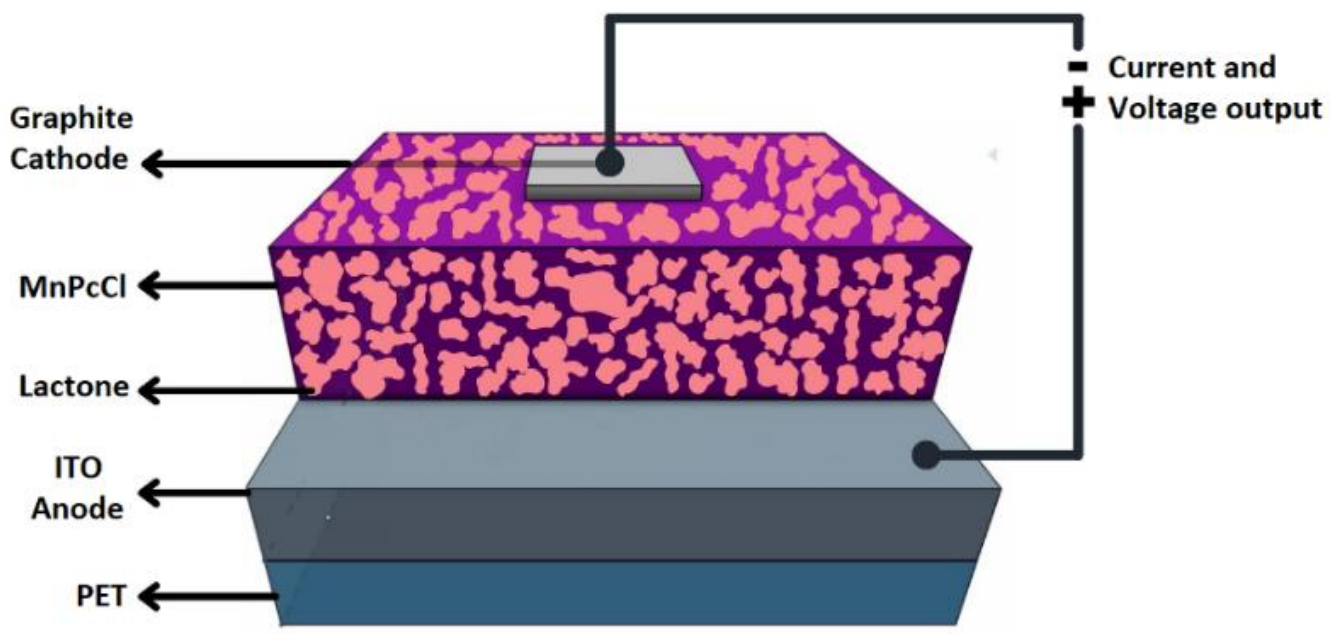

Figure 6. Cross section of the device.
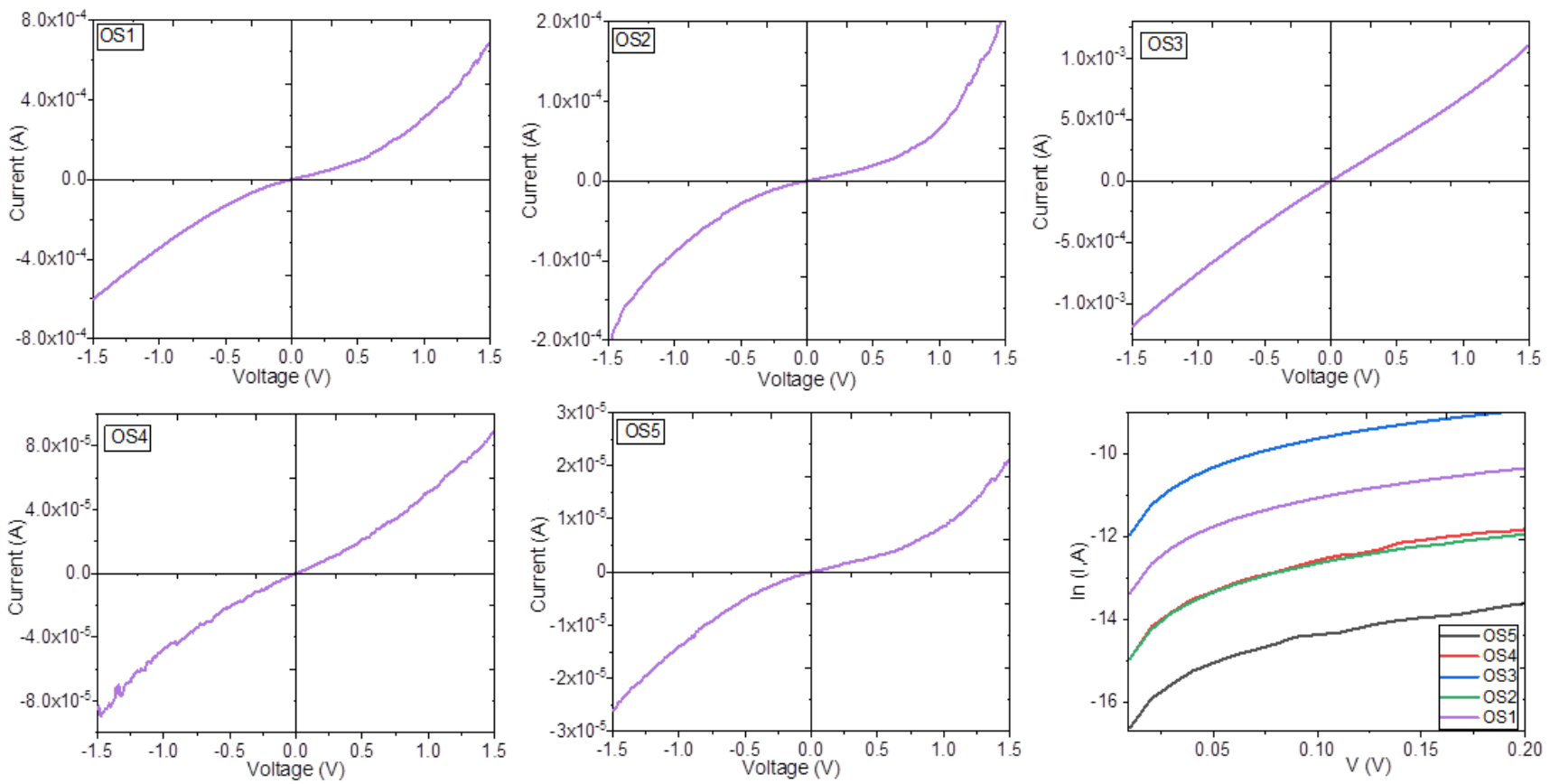

Figure 7. Current-Voltage (I-V) characteristic curves of the devices with OS films. 
Additionally, from Figure 7, it is evident that the presence of chalcone significantly modifies the semiconductor's behavior. The devices with films OS3 and OS4 show a quasi-ohmic behavior, which may allow their use as electrodes in optoelectronic devices; this dependence could be related to the injection of charges towards the semiconductor. On the other hand, there is no noticeable rectification at the $I-V$ curve of the device with film OS2; the symmetrical behavior is related to the ambipolarity of the device, as film OS2 can transport both electrons and holes. For this semiconductor, one obtains $\mathrm{E}_{\mathrm{g}}{ }^{\text {opt }}<1.8 \mathrm{eV}$ so that it may be used in the manufacture of optoelectronic devices such as thin-layer organic transistors [54,72] or active-layer solar cells [3,8]. Finally, in the $I-V$ curves for the devices with films OS1 and OS5, the existence of leakage current for OS1 and OS5 was observed [29]. This behavior is common in diode-type devices [73,74], although charge transport mechanisms should be studied in more detail. A semilogarithmic plot of the forward current vs. applied voltage for the same devices is shown in Figure 7. At applied voltages smaller than $0.002 \mathrm{~V}$, the logarithm of the current increases linearly; this suggests that thermionic emission may be the dominant conduction mechanism in such a potential range $[29,73]$. The extrapolated intercept of the linear portion of the curves with the $I$-axis, at $V=0 \mathrm{~V}$, yields the values of saturation current $\left(I_{\mathrm{s}}\right)$, which are reported in Table 2 [73]. Nevertheless, since the linearity range occurs in a very small interval (0.01-0.02 V), the dominant conduction mechanism for voltages higher than $0.02 \mathrm{~V}$ is defined by space-charge-limited current (SCLC) $[29,73,74]$. Within the contact between the electrodes and the semiconductor film, in the vicinity of the electrodes, spatial charges are formed which oppose the flow of current through the semiconductor film. Beyond a certain threshold in the applied field, current saturation occurs.

Table 2. Electrical parameters of the devices with OS films.

\begin{tabular}{|c|c|c|c|c|}
\hline Device & $I_{S}(\mathrm{~A})$ & $\begin{array}{l}\sigma \text { at } 0.1 \mathrm{~V} \\
\left(\mathrm{~S} \cdot \mathrm{cm}^{-1}\right)\end{array}$ & $\begin{array}{l}\sigma \text { at } 0.5 \mathrm{~V} \\
\left(\mathrm{~S} \cdot \mathrm{cm}^{-1}\right)\end{array}$ & $\begin{array}{l}\sigma \text { at } 1.0 \mathrm{~V} \\
\left(\mathrm{~S} \cdot \mathrm{cm}^{-1}\right)\end{array}$ \\
\hline OS1 & $2.24 \times 10^{-8}$ & $2.92 \times 10^{-2}$ & $3.16 \times 10^{-2}$ & $5.56 \times 10^{-2}$ \\
\hline OS2 & $2.32 \times 10^{-8}$ & $1.55 \times 10^{-5}$ & $1.89 \times 10^{-5}$ & $2.82 \times 10^{-5}$ \\
\hline OS3 & $1.18 \times 10^{-7}$ & $1.43 \times 10^{+1}$ & $1.51 \times 10^{+1}$ & $3.02 \times 10^{+1}$ \\
\hline OS4 & $2.73 \times 10^{-9}$ & $6.27 \times 10^{+0}$ & $8.26 \times 10^{+0}$ & $1.45 \times 10^{+1}$ \\
\hline OS5 & $7.14 \times 10^{-10}$ & $7.64 \times 10^{-1}$ & $7.64 \times 10^{-1}$ & $7.73 \times 10^{-1}$ \\
\hline
\end{tabular}

Electrical conductivity $(\sigma)$ is an important parameter; in semiconductor thin films, it increases with temperature. For each device, $\sigma$ was evaluated at applied voltages of $0.1,0.5$, and $1.0 \mathrm{~V}$ and at different temperatures. Table 2 shows the values of $\sigma$ at room temperature, while Figure 8 shows the temperature dependence of $\sigma$ at $0.5 \mathrm{~V}$ within a temperature range of 25 to $100{ }^{\circ} \mathrm{C}$. With respect to the results reported in Table 2, it is observed that, by increasing the voltage, an increase in the $\sigma$ of the device occurs, with the OS5 device presenting the highest conductivity. However, $\sigma$ values at room temperature for all devices are within the range for organic semiconductor materials $\left(10^{-6}\right.$ to $\left.10^{-1} \mathrm{~S} \cdot \mathrm{cm}^{-1}\right)$; this is important because an organic semiconductor is generally defined in terms of its conductivity at room temperature. These results are related to the chalcone presence and the features it contributes to the semiconductor: (i) a high electronic delocalization, permitting charge transport; (ii) an increase in the $\mathrm{BHJ}$ contact surface, which improves excitonic diffusion between $\mathrm{MnPcCl}$ and the chalcone, and (iii) a BHJ-generated anisotropy, producing conduction channels for charge transport. For the results in Figure 8, in all the devices, conductivity increases with temperature, as expected for semiconductors. Within the range, conductivity increases by two orders of magnitude in OS4 and less than an order of magnitude in OS1, OS2, OS3, and OS5. These results supplement earlier studies regarding the use of $\mathrm{MnPcCl}-$ chalcone semiconducting films for optoelectronic applications. 


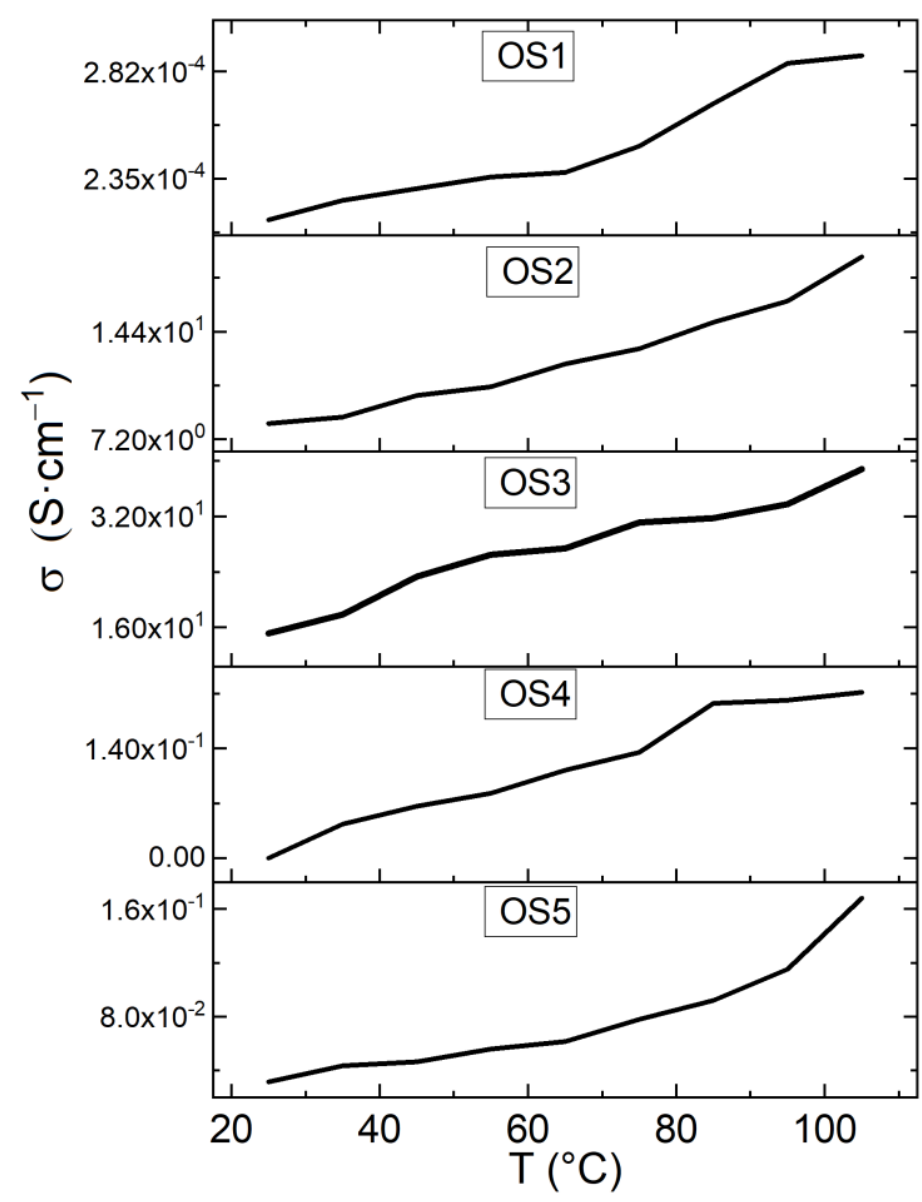

Figure 8. Electric conductivity $(\sigma)$ vs. T of the devices with OS films.

\section{Conclusions}

Organic semiconductors of $\mathrm{MnPcCl}$ and chalcones as dopants were prepared. Thin films of these semiconductors were deposited by high vacuum thermal evaporation, which is a technique that allows film deposition of high purity and uniform morphology. According to the IR spectroscopic results, the $\mathrm{MnPcCl}-$ chalcone organic semiconductors do not undergo degradation during the deposition process. $\mathrm{MnPcCl}-$ chalcone films showed the $Q$ band between $630-800 \mathrm{~nm}$, a band due to charge transfer in the region between 465 and $570 \mathrm{~nm}$, and the B band at region 280-460 nm. The films present two energy gaps: the optical band around $1.40 \mathrm{eV}$ and the fundamental gap around $2.35 \mathrm{eV}$. Electrical conductivity at room temperature varies from $1.8 \times 10^{-5}$ to $1.5 \times 10^{1} \mathrm{~S} \cdot \mathrm{cm}^{-1}$ and increases with temperature. Optoelectronic behavior and properties of the $\mathrm{MnPcCl}$-chalcone films are completely determined by the structure and type of chalcone, with the best properties arising in chalcones that have a methoxy group as a substituent. Thus, $\mathrm{MnPcCl}-$ chalcone doped semiconductors show promise, in terms of optical and electrical properties, for possible use in electronic devices.

Author Contributions: Conceptualization, M.E.S.V., M.J.C.J., G.C.R. and C.Á.T.; methodology, M.J.C.J., G.C.R., R.B.I. and M.E.S.V.; software M.E.S.V., M.J.C.J. and R.B.I.; validation, M.E.S.V., G.C.R., R.B.I., J.R.Á.B. and C.Á.T.; formal analysis, M.E.S.V., M.J.C.J., J.R.Á.B., R.B.I. and C.Á.T.; research, M.E.S.V., M.J.C.J., C.Á.T. and J.R.Á.B.; resources, M.E.S.V.; data curation, M.E.S.V. and R.B.I.; writing-original draft preparation, M.E.S.V., M.J.C.J., G.C.R., R.B.I. and C.Á.T.; writing-review and editing, M.E.S.V., R.B.I., J.R.Á.B. and C.Á.T.; visualization, M.E.S.V. and J.R.Á.B.; supervision, M.E.S.V. and C.Á.T.; project administration, M.E.S.V. and C.Á.T.; funding acquisition, M.E.S.V. and C.Á.T. All authors have read and agreed to the published version of the manuscript. 
Funding: M.E. Sánchez Vergara acknowledges the financial support from Universidad Anáhuac México, Project number NNAIASEVM16070616. C. Álvarez Toledano gratefully acknowledges the financial support of the DGAPA-PAPIIT Projet number IN203120.

Institutional Review Board Statement: Not applicable.

Informed Consent Statement: Not applicable.

Conflicts of Interest: The authors declare no conflict of interest.

\section{References}

1. Shoaee, S.; Sanna, A.L.; Sforazzini, G. Elucidating charge generation in green-solvent processed organic solar cells. Molecules 2021, 26, 7439. [CrossRef]

2. Moore, K.; Wei, W. Applications of carbon nanomaterials in perovskite solar cells for solar energy conversion. NMS 2021, 3, 276-290. [CrossRef]

3. Husain, A.A.F.; Hasan, W.Z.W.; Shafie, S.; Hamidon, M.S.; Pandey, S.S. A review of transparent solar photovoltaic technologies Renew. Sust. Energ. Rev. 2018, 94, 779-791. [CrossRef]

4. Green, M.; Dunlop, E.; Hohl-Ebinger, J.; Yoshita, M.; Kopidakis, N.; Hao, X. Solar cell efficiency tables (version 57). Prog. Photovolt. Res. Appl. 2021, 29, 3-15. [CrossRef]

5. Liu, Q.; Jiang, Y.; Jin, K.; Qin, J.; Xu, J.; Li, W.; Xiong, J.; Liu, J.; Xiao, Z.; Sun, K.; et al. 18\% Efficiency organic solar cells. Sci. Bull. 2020, 65, 272-275. [CrossRef]

6. Wu, J.; Gao, M.; Chai, Y.; Liu, P.; Zhang, B.; Liu, J.; Ye, L. Towards a bright future: The versatile applications of organic solar cells. MRE 2021, 1, 100062. [CrossRef]

7. Shi, D.; Guo, Z.; Bedford, N. 10-Nanoenergy materials. MNT 2015, 1, 255-291. [CrossRef]

8. Günes, S.; Neugebauer, H.; Sariciftci, N.S. Conjugated polymer-based organic solar cells. Chem. Rev. 2007, 107, 1324-1338. [CrossRef]

9. Gorduk, S.; Altindal, A. Peripherally tetra-substituted metallophthalocyanines bearing carboxylic acid groups for efficient dye sensitized solar cells. J. Mol. Struct. 2019, 1196, 747-753. [CrossRef]

10. Sukhikh, A.; Bonegardt, D.; Klyamer, D.; Krasnov, P.; Basova, T. Chlorosubstituted Copper phthalocyanines: Spectral study and structure of thin films. Molecules 2020, 25, 1620. [CrossRef]

11. Madhuri, K.P.; Sagade, A.A.; Santra, P.K.; John, N.S. Templating effect of single-layer graphene supported by an insulating substrate on the molecular orientation of lead phthalocyanine. Beilstein J. Nanotechnol. 2020, 11, 814-820. [CrossRef] [PubMed]

12. Zanotti, G.; Angelini, N.; Mattioli, G.; Paoletti, A.M.; Pennesi, G.; Caschera, D.; Sobolev, A.P.; Beverina, L.; Calascibetta, A.M.; Sanzone, A.; et al. [1]Benzothieno[3,2-b][1]benzothiophene-phthalocyanine derivatives: A subclass of solution-processable electron-rich hole transport materials. ChemPlusChem 2020, 85, 1-12. [CrossRef] [PubMed]

13. Cranston, R.R.; Lessard, B.H. Metal phthalocyanines: Thin-film formation, microstructure, and physical properties. RSC Adv. 2021, 11, 21716-21737. [CrossRef]

14. Williams, G.; Sutty, S.; Klenkler, R.; Aziz, H. Renewed interest in metal phthalocyanine donors for small molecule organic solar cells. Sol. Energy Mater. Sol. Cells. 2014, 124, 217-226. [CrossRef]

15. Grant, T.M.; Josey, D.S.; Sampson, K.L.; Mudigonda, T.; Bender, T.P.; Lessard, B.H. Boron subphthalocyanines and silicon phthalocyanines for use as active materials in organic photovoltaics. Chem. Rec. 2019, 19, 1093-1112. [CrossRef]

16. Reddy, G.; Devulapally, K.; Islavath, N.; Giribabu, L. Metallated macrocyclic derivatives as a hole-Transporting materials for perovskite solar cells. Chem Rec. 2019, 19, 2157-2177. [CrossRef]

17. Urbani, M.; de la Torre, G.; Nazeeruddin, M.K.; Torres, T. Phthalocyanines and porphyrinoid analogues as hole- and electrontransporting materials for perovskite solar cells. Chem. Soc. Rev. 2019, 48, 2738-2766. [CrossRef]

18. Yu, Z.; Hagfeldt, A.; Sun, L. The application of transition metal complexes in hole-transporting layers for perovskite solar cells: Recent progress and future perspectives. Coord. Chem. Rev. 2020, 406, 213143. [CrossRef]

19. Ranta, J.; Kaunisto, K.; Niskanen, M.; Efimov, A.; Hukka, T.I.; Lemmetyinen, H. Monoisomeric phthalocyanines and phthalocyanine-Fullerene dyads with polar side chains: Synthesis, modeling, and photovoltage. J. Phys. Chem. 2014, 118, 2754-2765. [CrossRef]

20. Martínez-Díaz, M.V.; de la Torre, G.; Torres, T. Lightning porphyrins and phthalocyanines for molecular photovoltaics. Chem. Commun. 2010, 46, 7090-7108. [CrossRef]

21. de la Torre, G.; Claessens, C.G.; Torres, T. Phthalocyanines: Old dyes, new materials. Putting color in nanotechnology. Chem. Commun. 2007, 2000-2015. [CrossRef] [PubMed]

22. Mack, J.; Kobayashi, N. Low symmetry phthlocyanines and their analogues. Chem. Rev. 2011, 111, 281-321. [CrossRef] [PubMed]

23. Martínez-Díaz, M.V.; Ince, M.; Torres, T. Phthalocyanines: Colorful macroheterocyclic sensitizers for dye-sensitized solar cells. Monatsh. Chem. 2011, 142, 699-707. [CrossRef]

24. El-Zaidia, E.F.M. Studies structure, surface morphology, linear and nonlinear optical properties of nanocrystalline thin films of manganese (III) phthalocyanine chloride for photodetectors application. Sens. Actuator 2021, 330, 112828. [CrossRef] 
25. Grobosch, M.; Mahns, B.; Loose, C.; Friedrich, R.; Schmidt, C.; Kortus, J.; Knupfer, M. Identification of the electronic states of manganese phthalocyanine close to the Fermi level. Chem. Phys. Lett. 2011, 505, 122-125. [CrossRef]

26. El-Nahass, M.M.; Soliman, H.S.; Khalifa, B.A.; Soliman, I.M. Structural and optical properties of nanocrystalline aluminum phthalocyanine chloride thin films. Mater. Sci. Semicond. Process. 2015, 38, 177-183. [CrossRef]

27. El-Zaidia, E.F.M.; Qashou, S.I.; Darwish, A.A.A.; Yahia, I.S. Thermally evaporated of homogeneous nanostructured galliumphthalocyanine-chloride films: Optical spectroscopy. Opt. Mater. 2020, 109, 110407. [CrossRef]

28. Darwish, A.A.A.; Hamdalla, T.A.; El-Zaidia, E.F.M.; Hanafy, T.A.; Issa, S.A.M.; Yahia, I.S. Thin films of nanostructured gallium (III) chloride phthalocyanine deposited on FTO: Structural characterization, optical properties, and laser optical limiting. Phys. $B$ Condens. Matter. 2020, 593, 412321. [CrossRef]

29. Zeyada, H.M.; El-Nahass, M.M.; El-Menyawy, E.M.; El-Sawah, A.S. Electrical and photovoltaic characteristics of indium phthalocyanine chloride/p-Si solar cell. Synth. Met. 2015, 207, 46-53. [CrossRef]

30. Soliman, I.M.; El-Nahass, M.M.; Khalifa, B.A. Characterization and photovoltaic performance of organic device based on $\mathrm{AlPcCl} / \mathrm{p}-\mathrm{Si}$ heterojunction. Synth. Met. 2015, 209, 55-59. [CrossRef]

31. Touka, N.; Benelmadjat, H.; Boudine, B.; Halimi, O.; Sebais, M. Copper phthalocyanine nanocrystals embedded into polymer host: Preparation and structural characterization. J. Assoc. Arab Univ. Basic Appl. Sci. 2013, 13, 52-56. [CrossRef]

32. Chau, L.K.; England, C.D.; Chen, S.; Armstrong, N.R. Visible absorption and photocurrent spectra of epitaxially deposited phthalocyanine thin films: Interpretation of exciton coupling effects. J. Phys. Chem. 1993, 97, 2699-2706. [CrossRef]

33. Sánchez-Vergara, M.E.; Rivera, M. Investigation of optical properties of annealed aluminum phthalocyanine derivatives thin films. J. Phys. Chem. Solids 2014, 75, 599-605. [CrossRef]

34. Soliman, I.M.; El-Nahass, M.M.; Mansour, Y. Electrical, dielectric and electrochemical measurements of bulk aluminum phthalocyanine chloride (AlPcCl). Solid State Commun. 2016, 225, 17-21. [CrossRef]

35. Rivera, M.; Reyes, B.; Sánchez-Vergara, M.E.; Mendoza-Huizar, L.H. Conductive Behavior and Morphology of Axially Modified Gallium Phthalocyanine Thin Films onto Indium Tin Oxide Substrates. AMPC 2016, 6, 211-219. [CrossRef]

36. Darwish, A.A.A.; Helali, S.; Qashou, S.I.; Yahia, I.S.; El-Zaidia, E.F.M. Studying the surface morphology, linear and nonlinear optical properties of manganese (III) phthalocyanine chloride/FTO films. Phys. B Condens. Matter. 2021, 622, 413355. [CrossRef]

37. Custodio, J.M.F.; Vaz, W.F.; Faria, E.C.M.; Anjos, M.M.; Campos, C.E.M.; Oliveira, G.R.; Martins, F.T.; da Silva, C.; Valverde, C.; Osório, F.A.P.; et al. On the potential as nonlinear optical material of a new chalcone derivative and its crystal and topological analysis. J. Mol. Struct. 2020, 1201, 127131. [CrossRef]

38. Ali, M.K.M.; Elzupir, A.O.; Ibrahem, M.A.; Suliman, I.I.; Modwi, A.; Idriss, H.; Ibnaouf, K.H. Characterization of optical and morphological properties of chalcone thin films for optoelectronics applications. Optik 2017, 145, 529-533. [CrossRef]

39. Vaz, W.; Custodio, J.; Silveira, R.; Castro, A.; Campos, C.; Anjos, M.; Oliveira, G.; Valverde, C.; Baseia, B.; Napolitano, H. Synthesis, Characterization, and third-order nonlinear optical properties of a new neolignane analogue. R. Soc. Chem. 2016, 6, 79215-79227. [CrossRef]

40. Sai Kiran, M.; Anand, B.; Siva Sankara Sai, S.; Nageswara Rao, G. Second- and third-order nonlinear optical properties of bis-chalcone derivatives. J. Photochem. Photobiol. A Chem. 2014, 290, 38-42. [CrossRef]

41. Abegão, L.M.G.; Fonseca, R.D.; Santos, F.A.; Souza, G.B.; Barreiros, A.L.B.S.; Barreiros, M.L.; Alencar, M.A.R.C.; Mendonça, C.R.; Silva, D.L.; De Boni, L.; et al. Second- and third-order nonlinear optical properties of unsubstituted and mono-substituted chalcones. Chem. Phys. Lett. 2016, 648, 91-96. [CrossRef]

42. Krawczyk, P.; Pietrzak, M.; Janek, T.; Jedrzejewska, B.; Cysewski, P. Spectroscopic and nonlinear optical properties of new chalcone fluorescent probes for bioimaging applications: A theoretical and experimental study. J. Mol. Model. 2016, 22, 125. [CrossRef] [PubMed]

43. Sarojini, B.; Narayana, B.; Ashalatha, B.; Indira, J.; Lobo, K. Synthesis, crystal growth and studies on non-linear optical property of new chalcones. J. Cryst. Growth. 2006, 295, 54-59. [CrossRef]

44. Gasull, E.; Blanco, S.; Ferretti, F. A theoretical and experimental study of adsorption from dilute cyclohexane solutions of non-electrolytes: 4-X-chalcones on silica gel. J. Mol. Struct. Teochem. 2002, 579, 121-137. [CrossRef]

45. Gu, C.L.; Liu, L.; Sui, Y.; Zhao, J.L.; Wang, D.; Chen, Y.J. Highly enantioselective Michael additions of $\alpha$-cyanoacetate with chalcones catalyzed by bifunctional cinchona-derived thioureaorganocatalyst. Tetrahedron Asymmetry 2007, 18, 455-463. [CrossRef]

46. Maidur, S.R.; Patil, P.S. Z-scan studies of third-order nonlinear optical and optical limiting properties of chalcones doped Poly(methyl methacrylate) thin films for visible laser protection. Opt. Mater. 2018, 84, 28-37. [CrossRef]

47. Vidyashree, H.; Bhajantri, R.F.; Jagadish, N.; Sunil, G.R. Thiazole yellow G dyed PVA films for optoelectronics: Microstructural, thermal and photophysical studies. Mater. Res. Express 2016, 3, 075301. [CrossRef]

48. Sweeting, S.G.; Hall, C.L.; Potticary, J.; Pridmore, N.E.; Warren, S.D.; Cremeens, M.E.; D’ Ambruoso, G.D.; Matsumoto, M.; Hall, S.R. The solubility and stability of heterocyclic chalcones compared with trans-chalcones. Acta Cryst. 2020, B76, 13-17. [CrossRef]

49. Asiri, A.M.; Khan, S.A. Synthesis, characterization and optical properties of mono-and bischalcone. Mater. Lett. 2011, 65, 1749-1752. [CrossRef]

50. Janardhana, K.; Ravindrachary, V.; Kumar, P.R. Third order nonlinear optical studies of 1-(4- chloro phenyl)-3-(4-dimethylamino phenyl) prop-2-en-1-one. J. Cryst. Growth. 2013, 368, 11-20. [CrossRef]

51. Devi, J.M.; Tharmaraj, J.; Ramakrishnan, S.; Ramachandran, K. On the thermal properties of metal (II) complexes of chalcone. Mater. Lett. 2008, 62, 852-856. [CrossRef] 
52. Praveen, A.; Jayarama, A. Crucial role of molecular planarity on the second order nonlinear optical property of pyridine based chalcone single crystals. J. Mol. Struct. 2015, 1088, 85-94. [CrossRef]

53. Carmona-Reyes, G.; Ballinas-Indili, R.; Sánchez-Vergara, M.E.; Toscano, R.A.; Álvarez-Toledano, C. Regiodivergent synthesis of vinyl trifluoromethansulfonates c/d lactones: Via 1,6 addition/intramolecular one-pot annulation of 1,4-dihidropyridines derivated from pyridinyl propenones. Tetrahedron Lett. 2022, 88, 153591. [CrossRef]

54. El-Nahass, M.M.; Abd-El-Rahman, K.F.; Al-Ghamdi, A.A.; Asiri, A.M. Optical properties of thermally evaporated tinphthalocyanine dichloride thin films, SnPcCl2. Phys. B Condens. Matter. 2014, 344, 398-406. [CrossRef]

55. Hart, M.M. Cationic Exchange Reactions Involving Dilithium Phthalocyanine. Master's Thesis, Wright State University, Dayton, OH, USA, 2009.

56. Maidur, S.R.; Patil, P.S. Linear optical and third-order nonlinear optical properties of anthracene chalcone derivatives doped PMMA thin films. Optik 2019, 190, 54-67. [CrossRef]

57. Sun, J.; Wang, G.; Liu, C.; Shi, Y.; Zhao, M. Synthesis of four pyrene-containing chalcone derivatives: Achieving excellent third-order nonlinear optical properties by optimizing halopyridines. Opt. Laser Technol. 2019, 109, 600-607. [CrossRef]

58. El-Nahass, M.M.; Farag, A.M.; Abd El-Rahman, K.F.; Darwish, A.A.A. Dispersion studies and electronic transitions in nickel phthalocyanine thin films. Opt. Laser Technol. 2005, 37, 513-523. [CrossRef]

59. Özçeșmeci, M.; Nar, I.; Hamuryudan, E. Synthesis and electrochemical and spectroelectrochemical characterization of chloromanganese(III) phthalocyanines. Turk. J. Chem. 2014, 38, 1064-1072. [CrossRef]

60. Maidur, S.R.; Jahagirdar, J.R.; Patil, P.S.; Chia, T.S.; Quah, C.K. Structural characterizations, Hirshfeld surface analyses, and thirdorder nonlinear optical properties of two novel chalcone derivatives. Opt. Mater. 2018, 75, 580-594. [CrossRef]

61. Lu, M.; Wang, K.; Han, Y.; Yao, Y.; Gao, P.; Huang, C.; Zhang, W.; Xu, F. Synthesis, structure, and optical properties of manganese phthalocyanine thin films and nanostructures. Prog. Nat. Sci. Mater. Int. 2017, 27, 329-332. [CrossRef]

62. Mahmoud, A.Z.; Darwish, A.A.A.; Qashou, S.I. Film thickness effects on nanorods organic films of azo quinoline derivatives for optical applications. Prog. Nat. Sci. Mater. Int. 2019, 29, 402-409. [CrossRef]

63. Elesh, E.; Mohammed, Z. Morphological, linear and nonlinear properties of gallium phthalocyanine chloride annealed thin films Optik 2020, 219, 165176. [CrossRef]

64. El-Nahass, M.M.; El-Deeb, A.F.; Metwally, H.S.; Hassanien, A.M. Influence of annealing on the optical properties of 5,10,15,20tetraphenyl-21H, 23H-porphine iron (III) chloride thin films. Mater. Chem. Phys. 2011, 125, 247-251. [CrossRef]

65. Bardeen, J.; Blatt, F.J.; Hall, L.H. Energy Dependence of Indirect Optical Absorption in Semiconductors. In Proceedings of the Conference on Photoconductivity; Atlantic: Boston, MA, USA, 4-6 November 1965; p. 149.

66. Dongol, M.; El-Nahass, M.; El-Denglawey, A.; Elhady, A.; Abuelwafa, A. Optical Properties of Nano 5,10,15,20-Tetraphenyl21H,23H-Prophyrin Nickel (II) Thin Films. Curr. Appl. Phys. 2012, 12, 1178-1184. [CrossRef]

67. Alghamdi, S.A.; Darwish, A.A.A.; Yahia, I.S.; El-Zaidia, E.F.M. Structural characterization and optical properties of nanostructured indium (III) phthalocyanine chloride/FTO thin films for photoelectric applications. Optik 2021, 239, 166780. [CrossRef]

68. Alharbi, S.R.; Darwish, A.A.A.; Al Garni, S.E.; El Saeedy, H.I.; Abd El-Rahman, K.F. Influence of thickness and annealing on linear and nonlinear optical properties of manganese (III) chloride tetraphenyl porphine (MnTPPCl) organic thin films. Infrared Phys. Technol. 2016, 78, 77-83. [CrossRef]

69. Van Duren, J.; Yang, X.N.; Loos, J.; Bulle-Liewma, C.W.T.; Sieval, A.B.; Hummelen, J.C.; Janssen, R.A.J. Relating the Morphology of Poly( $p$-phenylene vinylene)/Methanofullerene Blends to Solar-Cell Performance. Adv. Mater. 2004, 14, 425. [CrossRef]

70. Reyes-Reyes, M.; Kim, K.; Carroll, D.L. High-efficiency photovoltaic devices based on annealed poly(3-hexylthiophene) and 1-(3-methoxycarbonyl)-propyl-1- phenyl-(6,6)C61(6,6)C61 blends. Appl. Phys. Lett. 2005, 87, 083506. [CrossRef]

71. Peet, J.; Kim, J.Y.; Coates, N.E.; Ma, W.L.; Moses, D.; Heeger, A.J.; Bazán, G.C. Efficiency enhancement in low-bandgap polymer solar cells by processing with alkane dithiols. Nat. Mater. 2007, 6, 497. [CrossRef]

72. Meijer, E.J.; de Leeuw, D.M.; Setayesh, S.; van Veenendaal, E.; Huisman, B.H.; Blom, P.W.M.; Hummelen, J.C.; Scherf, U.; Klapwijk, T.M. Solution-processed ambipolar organic field-effect transistors and inverters. Nat. Mater. 2003, 2, 678. [CrossRef]

73. Shafai, T.S.; Anthopoulous, T.D. Junction properties of nickel phthalocyanine thin film devices utilizing indium injecting electrodes. Thin Solid Film. 2001, 398-399, 361-367. [CrossRef]

74. Ahmad, Z.; Sayyad, M.H.; Karimov, K.S. CuPc based organic-inorganic hetero-junction with Au electrodes. J. Semicond. 2010, 31, 074002-1-4. [CrossRef] 